\title{
Snacking Among US Children: Patterns Differ by Time of Day
}

\author{
Dantong Wang, PhD, MPH; Klazine van der Horst, $\mathrm{PhD}, \mathrm{MPH}$; \\ Emma Jacquier, MMedSci; Alison L. Eldridge, PhD, RD
}

\begin{abstract}
Objective: Evaluate foods and beverages consumed, and energy and nutrient densities that constitute morning, afternoon, and evening snacking periods among children in the US.

Design: Evaluate snacking behavior using the National Health and Nutrition Examination Survey, 2009-2012.

Participants: Children aged $4-8$ and $9-13$ years $(n=3,647)$.

Variables Measured: Self-reported foods and beverages reported as snacks were aggregated into morning (0:00-12:00 hours), afternoon (12:00-18:00 hours), and evening (18:00-24:00 hour) snacking periods.

Analysis: Intakes and amounts consumed during different snacking periods were analyzed from per capita weighted averages using SAS 9.2 and SUDAAN software. Statistical differences were detected using Student $t$ test for means and chi-square test for prevalence data.

Results: Snacking contributed $25 \%$ of daily energy in both age groups, with the morning snacking period contributing the least energy. The most frequently consumed food groups across all snacking periods were water, snacks and sweets, nonalcoholic beverages, milk and dairy, and fruit. Nutrient densities varied among different snacking periods; the morning snack period for 4- to 8-year-olds was the most nutrient dense.

Conclusions and Implications: Snacking is an important contributor to energy and nutrients in children's diets, but foods and beverages selected vary by time of day and age. Modifying snacking choices, especially in the afternoon, could improve the nutritional quality of children's diets.

Key Words: child, snacks, time of day, nutrients, National Health and Nutrition Examination Survey $(J$ Nutr Educ Behav. 2016;48:369-375.)
\end{abstract}

Accepted March 20, 2016. Published online April 20, 2016.

\section{INTRODUCTION}

Snacking between meals is growing in importance as an eating occasion for children across the world. ${ }^{1}$ In the US, the percentage of children snacking on any given day has increased from $74 \%$ in $1977-1978$ to $98 \%$ in $2003-$ $2006 .^{2}$ Children ate or drank between meals 2-3 times/d on average, which accounted for $27 \%$ of their daily total energy intake in 2003-2006. ${ }^{2}$ Data from the most recent National Health and Nutrition Examination Survey (NHANES), 2011-2012, showed that approximately $25 \%$ of children and adolescents consumed some food or beverage (including water) between meals $\geq 4$ times/d.

There are increasing concerns about the types of foods and beverages, their nutritional quality, and the amount of energy snacking provides, particularly in the US, where childhood obesity is a public health issue. Snacking frequency was positively associated with

Public Health Nutrition, Nestlé Research Center, Lausanne, Switzerland

Conflict of Interest Disclosure: The authors' conflict of interest disclosures can be found online with this article on www.jneb.org.

Address for correspondence: Dantong Wang, PhD, MPH, Public Health Nutrition, Nestlé Research Center, Vers-Chez-Les-Blanc, PO Box 44, Lausanne 26, Switzerland CH-1000; Phone: +(41-21) 785-8569; Fax: +(41-21) 785-8308; E-mail: dantong.wang@rdls.nestle.com (C)2016 The Authors. Published by Elsevier, Inc. on behalf of the Society for Nutrition Education and Behavior. This is an open access article under the CC BY-NC-ND license (http://creativecommons.org/licenses/by-nc-nd/4.0/).

http://dx.doi.org/10.1016/j.jneb.2016.03.011

Journal of Nutrition Education and Behavior • Volume 48, Number 6, 2016

energy intake in 9- to 15-year-olds from the greater Boston area, with each snacking occasion contributing an average increase of $9.4 \%$ to total energy for the day. ${ }^{4}$ Dessert items (cookies, cakes, pies, bars, ice cream, and gelatin desserts) and sweetened beverages (soft drinks, fruit drinks, and sports drinks) provided the most energy from snacks among 2- to 18-year-olds from 1989-1991 to 2003-206, with the largest increases over time from salty snack and candy consumption. ${ }^{2}$ The nutritional quality of foods and beverages consumed as snacks is mixed. Relative to their energy contribution, snacks contributed a disproportionately lower proportion of some micronutrients in the diet of children, such as iron, selenium, zinc, and B vitamins, but their contribution to vitamin $\mathrm{C}$ was higher. $^{5}$

There is emerging evidence that the consumption of snacks may make different nutrient contributions to the diets of younger children compared 
with the diets of older ones. Snacks were positively associated with increased Healthy Eating Index scores among Boston-area elementary school-age children but not in adolescents, which could be due to decreased consumption of fruit, $100 \%$ fruit juice, milk, and milk products as snacks among 12- to 15year-olds. ${ }^{4}$ A national survey in Mexico found that among young children (aged 2-5 years), fruit was the food most frequently consumed during snacking, whereas for older children (aged 6-11 years), salty snacks were most frequently consumed. ${ }^{6}$ This raises the question of how much snacking behaviors, eg, the foods consumed and nutrients provided by snacks, might differ between younger and older children in a nationally representative sample of the US population.

Recent studies have also shown that the percentages of snack consumers differed between younger and older children at different snacking occasions in a day. ${ }^{6,7}$ Timing of meals has been found to be important in influencing overall energy intake, in which intakes in the morning were associated with a reduction and intakes at night were associated with an increase of total daily energy intake in adults. ${ }^{8-10}$ Late energy intake and evening snacking have also been associated with certain health risks in children, such as obesity and risk for developing metabolic syndrome. ${ }^{11,12}$ The review of Kinsey and Ormsbee $^{13}$ highlighted the importance of meal timing in nutrient intake and metabolism. However, little is known about the characteristics of snacks at different times across a day, which could affect total energy and nutrient intakes. Therefore, a better understanding of types of foods eaten as snacks at different times across the day and their contribution to energy and nutrient intakes among younger and older children is needed. Such data may lead to opportunities of better educating caregivers and children about when they eat each day and what they are consuming as snack foods.

The objective of this analysis was to evaluate the timing of snack consumption (called the snacking period in this study) and the types of foods and beverages that are consumed during morning, afternoon, and evening snacking periods among US children. To get a more complete picture of snacking events, this study also exam- ined the contribution of snacks to total energy intakes and to nutrient densities for key nutrients during these snacking periods.

\section{METHODS}

Data from NHANES 2009-2012 were used for this study. The National Center for Health Statistics Research Ethics Review Board approved all NHANES protocols and each participant provided informed consent before completing any questionnaires or measurements. The secondary data analysis conducted for this study used publicly available NHANES de-identified data and was exempt from further approval from the National Center for Health Statistics Research Ethics Review Board. The NHANES uses a complex, multistage probability sample design that includes a nationally representative sample of the US civilian, all non-institutionalized people living in households. ${ }^{14}$ Dietary intake data from 2 nonconsecutive days of 24-hour recalls covering both weekdays and weekends were collected by trained interviewers using the automated multiple-pass method developed by the US Department of Agriculture (USDA). ${ }^{15}$ Proxy respondents were used to collect dietary data for children aged $\leq 5$ years. Interviews for 6- to 11-year-olds were assisted by proxy. From the age of 12 years, participants reported their own intakes. Data from 3,647 children aged 4-13 years in NHANES 2009-2012 were included in this analysis.

The USDA What We Eat in America food grouping system was applied to classify all foods and beverages consumed into 150 mutually exclusive food categories arranged in 3 hierarchical levels. ${ }^{16}$ Day 1 dietary weights were used to calculate the per capita weighted means of foods and beverages consumed as representative of the US population. Snacking was defined by the subject's self-report on meal occasions in the survey questionnaires; time of snack was also recorded. Snacking occasions were categorized into morning, afternoon, and evening snacking periods for snacking events reported between 0:00 and 12:00, 12:00 and 18:00 and 18:00 and 24:00 hours, respectively. All foods and beverages reported as snacks were included in the analysis. For the purposes of food group analysis and nutrient calculations, multiple eating events were combined by time of day when children reported more than 1 snack within the morning, afternoon, or evening eating periods. For example, if a child reported 2 snacks between 12:00 and 18:00 hours, they would be combined and analyzed as afternoon snacking. Therefore, there were a maximum of 3 possible snacking periods in a day for each subject. To represent meals other than snacks, breakfast, lunch, and dinner were combined and are referred as the meals in this study.

Data were stratified by age into 2 groups (4-8 and 9-13 years) and categorized by snacking periods (morning, afternoon, and evening). Foods and beverages consumed between meals were reported by food categories defined by the USDA. Based on their importance as energy sources and their roles in child health and growth, nutrient densities of selected macroand micronutrients (ie, protein, fat, sugar, dietary fiber, calcium, sodium, and vitamins $C$ and D) were calculated for each snacking period and expressed as grams, milligrams, or micrograms per 100 kcal. SAS 9.2 (SAS Institute, Inc., Cary, NC, 2008) and SUDAAN 11 (RTI International, RTP, NC, 2012) were used for calculations. Student $t$ was used to detect the statistical difference of means (such as mean energy intakes between different snacking periods) and chi-square was used to test prevalence data (such as the percentage of children consuming snacks at different snacking periods) $(P \leq .05)$. Bonferroni adjustment was applied to adjust for multiple comparisons.

\section{RESULTS}

Distribution of Snacking

Periods Among US Children Aged 4-13 Years

Nearly all children (about 96\%) reported consuming snacks during at least 1 snacking period on any given day (Table 1). About $45 \%$ of children reported snacking during 2 snacking periods a day, whereas only about $25 \%$ reported snacks during either 1 or 3 snacking periods per day. No statistically significant differences were found for snacking period frequency between the 2 age groups or between boys and girls. Among 
Table 1. Percentage of 4- to 13-Year-Old US Children Consuming Snacks and Distribution of Snacking Periods, From National Health and Nutrition Examination Survey 2009-2012

\begin{tabular}{cccccccc} 
& \multicolumn{3}{c}{ Aged 4-8 $\mathbf{y}$} & \multicolumn{3}{c}{ Aged 9-13 y } \\
& Male & Female & Total & Male & Female & Total \\
& $\mathbf{n}=\mathbf{1 , 0 0 8}$ & $\mathbf{n}=\mathbf{9 0 9}$ & $\mathbf{n}=\mathbf{1 , 9 1 7}$ & $\mathbf{n}=\mathbf{8 4 8}$ & $\mathbf{n = 8 8 2}$ & $\mathbf{n}=\mathbf{1 , 7 3 0}$ \\
\multicolumn{4}{r}{ Snacking period count [\% (SE)] } & & & & \\
0 & $4.1(0.9)$ & $2.6(0.7)$ & $3.4(0.7)$ & $5.3(1.2)$ & $5.2(1.5)$ & $5.2(0.9)$ \\
1 & $23.2(2.1)$ & $25.0(2.6)$ & $24.0(1.8)$ & $26.3(2.0)$ & $25.1(2.5)$ & $25.7(1.9)$ \\
2 & $46.4(2.0)$ & $46.8(2.5)$ & $46.6(1.8)$ & $43.5(2.2)$ & $46.7(3.0)$ & $45.2(1.7)$ \\
3 & $26.3(2.0)$ & $25.6(2.6)$ & $26.0(1.7)$ & $25.0(2.4)$ & $23.0(3.6)$ & $23.9(2.2)$ \\
Snacking period [\% (SE)] & & & & & \\
Morning & $48.4(3.1)$ & $48.1(3.0)$ & $48.3(2.2)$ & $44.8(2.7)$ & $45.9(3.8)$ & $45.4(2.4)$ \\
Afternoon & $78.9(2.5)$ & $80.7(1.9)$ & $79.7(1.5)$ & $75.1(2.2)$ & $76.3(2.6)$ & $75.8(1.8)$ \\
Evening & $67.6(3.0)$ & $66.6(2.0)$ & $67.2(2.1)$ & $68.1(2.6)$ & $65.3(3.2)$ & $66.6(2.1)$ \\
Any period & $95.9(0.9)$ & $97.4(0.7)$ & $96.6(0.7)$ & $94.7(1.2)$ & $94.8(1.5)$ & $94.8(0.9)$ \\
\hline
\end{tabular}

Table 2. Frequently Reported Foods and Beverages in US Children Aged 413 Years: Percent Consumed and Mean Energy Contribution During Each Snacking Period

\begin{tabular}{|c|c|c|c|c|c|}
\hline \multirow[b]{2}{*}{$\begin{array}{l}\text { Snacking } \\
\text { Period }\end{array}$} & \multirow[b]{2}{*}{ Food Group } & \multicolumn{2}{|c|}{$4-8$ y $(n=1,917)$} & \multicolumn{2}{|c|}{$9-13$ y $(n=1,730)$} \\
\hline & & $\begin{array}{c}\% \\
\text { Consuming }\end{array}$ & $\begin{array}{c}\text { Per Capita } \\
\text { Energy, } \\
\text { kcal (SE) }\end{array}$ & $\begin{array}{c}\% \\
\text { Consuming }\end{array}$ & $\begin{array}{c}\text { Per Capita } \\
\text { Energy, } \\
\text { kcal (SE) }\end{array}$ \\
\hline \multirow{5}{*}{ Morning } & Water $^{\mathrm{a}}$ & 30.4 & $0(0.1)$ & 28.4 & $0(0.1)$ \\
\hline & $\begin{array}{l}\text { Snacks and } \\
\text { sweets }^{b}\end{array}$ & 18.2 & $28(2.6)$ & 17.7 & $32(3.6)$ \\
\hline & Beverages $^{c}$ & 9.8 & $12(2.3)$ & 10.1 & $16(3.2)$ \\
\hline & Milk and dairy ${ }^{d}$ & 7.6 & $11(1.3)$ & $4.0^{*}$ & $9(2.2)$ \\
\hline & Fruit $^{\mathrm{e}}$ & 5.4 & $4(0.7)$ & 4.8 & $5(1.1)$ \\
\hline \multirow[t]{5}{*}{ Afternoon } & $\begin{array}{l}\text { Snacks and } \\
\text { sweets }^{\mathrm{b}}\end{array}$ & 56.7 & $122(4.7)$ & $48.0^{*}$ & $119(5.9)$ \\
\hline & Beverages $^{\circ}$ & 28.1 & $31(2.0)$ & 26.4 & $34(3.4)$ \\
\hline & Water $^{a}$ & 24.8 & $0(0.2)$ & 22.9 & $0(0.1)$ \\
\hline & Fruit $^{e}$ & 18.8 & $16(1.9)$ & $11.4^{*}$ & $10(1.1)^{\star}$ \\
\hline & Milk and dairy ${ }^{d}$ & 18.6 & $23(2.1)$ & $12.7^{*}$ & $18(2.4)$ \\
\hline \multirow[t]{5}{*}{ Evening } & $\begin{array}{l}\text { Snacks and } \\
\text { sweets }^{b}\end{array}$ & 38.3 & $80(5.2)$ & 41.3 & $115(9.2)^{*}$ \\
\hline & Water $^{2}$ & 18.9 & $0(0.0)$ & 20.2 & $0(0.2)$ \\
\hline & Milk and dairy ${ }^{d}$ & 18.8 & $27(4.3)$ & $14.3^{\star}$ & $22(3.5)$ \\
\hline & Beverages $^{c}$ & 17.1 & $14(1.1)$ & $20.5^{\star}$ & $22(2.7)^{\star}$ \\
\hline & Fruit $^{\mathrm{e}}$ & 7.6 & $6(0.6)$ & 8.9 & 7 (1.3) \\
\hline
\end{tabular}

aWater includes plain tap and bottled water, carbonated water, and flavored or fortified water; ' ${ }^{\text {S }}$ acks and sweets include savory snacks (potato chips, tortilla and corn chips, popcorn, and pretzels), crackers, cereal and nutrition bars, sweet bakery products (cakes, pies, cookies, brownies, donuts, sweet rolls, and pastries), candy, and other desserts (ice cream and frozen dairy desserts, pudding, gelatins, ices, and sorbets); 'Nonalcoholic beverages include 100\% juice, diet beverages, sweetened beverages (soft drinks, fruit drinks, sports and energy drinks, and nutritional beverages), coffee, and tea; 'Milk and dairy include milk, flavored milk, dairy drinks, cheese, and yogurt; ${ }^{e}$ Fruit includes all types of fruits and fruit salads; ${ }^{\star} P<.05$ compared with corresponding values in the 4- to 8-year-old group using chi-square test for the percentage and $t$ test for mean comparisons (Bonferroni adjustment was applied). the 3 snacking periods, the afternoon period was the most popular one reported by $75 \%$ to $80 \%$ children, followed by the evening period with $65 \%$ to $68 \%$. Less than $50 \%$ reported having snacks during the morning period.

\section{Foods and Beverages Consumed as Snacks Between Meals}

Table 2 lists the most frequently reported foods and beverages consumed as snacks. The major food categories of water, snacks and sweets, beverages (nonalcoholic), milk and dairy, and fruit were among the top 5 food groups consumed in all snacking periods for both age groups, although the order varied. During the morning snacking period, water was the most reported food group, followed by snacks and sweets. In the afternoon and evening snacking periods, snacks and sweets was the most frequently consumed food group for both age groups. Compared with 4- to 8-year-olds, children aged 9-13 years were less likely to consume foods from the milk and dairy category in all snacking periods $(P<.05)$. In the afternoon snacking period, the percentage of children consuming fruit or snack and sweet foods was lower among 9- to 13-yearolds compared with 4- to 8-year-olds $(P<.05)$. In the evening snacking period, beverage consumption was higher in older children compared with younger ones $(P<.05)$. The snacks and sweets group contributed the most energy in all snacking periods across age groups.

Specific subgroups within each major food group category are shown in Table 3. Compared with 4- to 8-yearolds, 9- to 13-year-old children had lower percentages of milk and dairy product consumption, including milk, flavored milk, cheese, and yogurt. The percentage of 9- to 13-year-old children who consumed crackers, $100 \%$ juice, and some fruit was also lower than that of 4- to 8-year-olds. Although the percentage of 9- to 13-year-old children who consumed savory snacks and sweetened beverages was not statistically higher than that of 4- to 8-year-olds, these foods contributed significantly more energy they did in the younger child group, which suggests that the older 
Table 3. Percentage of Food and Beverage Consumption and Mean Energy Contribution in 4- to 13-Year-Old US Children: Breakdown of Major Food Groups

\begin{tabular}{|c|c|c|c|c|c|}
\hline \multirow{2}{*}{$\begin{array}{l}\text { Main Food } \\
\text { Group }\end{array}$} & \multirow[b]{2}{*}{ Sub-Food Group } & \multicolumn{2}{|c|}{$4-8$ y $(n=1,917)$} & \multicolumn{2}{|c|}{$9-13$ y $(n=1,730)$} \\
\hline & & $\%$ & kcal (SE) & $\%$ & kcal (SE) \\
\hline \multirow[t]{5}{*}{$\begin{array}{l}\text { Snacks and } \\
\text { sweets }\end{array}$} & $\begin{array}{l}\text { Sweet bakery } \\
\text { products }\end{array}$ & 33.4 & $80(4.3)$ & 30.1 & $92(7.6)$ \\
\hline & Savory snacks & 30.5 & $47(2.7)$ & 32.9 & $65(5.5)^{\star}$ \\
\hline & Candy & 30.0 & $39(4.0)$ & 30.2 & $46(5.7)$ \\
\hline & Other desserts & 20.0 & $32(3.4)$ & 18.0 & $42(5.2)$ \\
\hline & Crackers & 15.7 & $25(3.1)$ & $10.7^{\star}$ & $16(2.4)$ \\
\hline \multirow[t]{4}{*}{ Beverages $^{a}$} & Sweetened beverages & 30.4 & $38(2.1)$ & 32.1 & $52(4.5)^{*}$ \\
\hline & $100 \%$ juice & 13.8 & $16(2.4)$ & $6.3^{\star}$ & $9(1.8)$ \\
\hline & Coffee and tea & 4.0 & 4 (1.9) & $8.2^{*}$ & $10(2.4)$ \\
\hline & Diet beverages & 3.0 & $0(0.0)$ & $6.5^{\star}$ & $0(0.1)$ \\
\hline \multirow[t]{5}{*}{ Milk and dairy } & Milk & 20.3 & $25(1.9)$ & $16.1^{*}$ & $25(3.6)$ \\
\hline & Cheese & 11.3 & $14(2.4)$ & $7.8^{\star}$ & $8(1.1)$ \\
\hline & Flavored milk & 6.4 & $14(2.7)$ & $2.9^{\star}$ & $6(1.5)$ \\
\hline & Yogurt & 5.4 & $6(1.2)$ & $2.6^{\star}$ & $4(1.0)$ \\
\hline & Dairy drinks ${ }^{b}$ & 1.8 & $6(0.5)$ & 1.7 & $5(2.1)$ \\
\hline \multirow[t]{5}{*}{ Fruit } & Apples & 9.0 & $7(0.8)$ & 8.7 & $7(0.9)$ \\
\hline & Bananas & 6.1 & $6(0.6)$ & $3.9^{*}$ & $4(0.9)$ \\
\hline & Citrus fruit & 4.9 & $3(0.5)$ & 3.7 & $3(0.6)$ \\
\hline & Grapes & 4.6 & $3(0.7)$ & $2.7^{\star}$ & $2(0.4)$ \\
\hline & Berries & 2.9 & $1(0.1)$ & 3.2 & $1(0.7)$ \\
\hline
\end{tabular}

$\%$ indicates the percentage of children who reported having snacks; kcal, energy intake per capita.

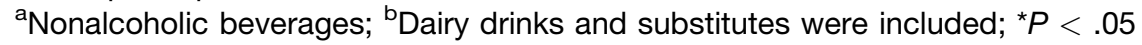
compared with corresponding values in the 4- to 8-year-old group using chisquare test for the percentage and $t$ test for mean comparisons (Bonferroni adjustment was applied).

children increased the amounts consumed of these foods and beverages.

\section{Energy Contribution of Each Snacking Period}

On average, snacks contributed 460 and $504 \mathrm{kcal}$ in the 4 - to 8-year-old and 9- to 13-year-old groups, respectively, which corresponded to $25 \%$ of their daily energy intake in each age group (Table 4). The morning snacking period provided the least energy of the 3 snacking periods (around $3.5 \%$ of daily energy intake). In 4 - to 8-year-olds, afternoon snacks contributed the most energy $(P<.05)$ which was consistent with the high percentage of consumers shown in Table 1. In both age groups, afternoon and evening snacking periods contributed substantially to total energy intake. No statistically significant differences were found between boys and girls.

\section{Nutrient Densities of Snacks Consumed During Different Snacking Periods}

The nutrient density of selected nutrients was calculated for each snacking period and for all other meals combined. As shown in Table 5, compared with nutrient densities of other meals, snacks in general were lower in protein, total and saturated fat, vitamin $\mathrm{D}$, and sodium but higher in total and added sugar, and vitamin $C$ $(P<.05)$. The densities of calcium and dietary fiber were similar to those of other meals that were at a low level in general compared with dietary intake recommendations. Among the 3 snacking periods, the morning was higher in calcium and vitamin C, and lower in added sugar (for 4- to 8year-olds) and saturated fat (for 9- to 13-year-olds) $(P<.05)$. The afternoon snacking period was lower in calcium and vitamin $\mathrm{D}$, whereas the evening period was higher in saturated fat $(P<.05)$. In the morning, the density of added sugar for 9- to 13-year-old children was higher, and the densities of protein and vitamin $\mathrm{D}$ were lower than for 4- to 8-year-old children.

\section{DISCUSSION}

Many investigators have evaluated different aspects of child snacking, such as calorie intake from snacks, ${ }^{2}$ snacking location, ${ }^{17}$ the influence of the shape of snacks in snacking intake, $^{18}$ after-school snack intake, ${ }^{19}$ and the quality of snacks in primary and secondary schools. ${ }^{4}$ In this study, snacking behavior during morning, afternoon, and evening snacking periods was examined, with an analysis of the food groups consumed, as well as energy and nutrient intakes provided by snacks during each of these periods. The results from this study provide important insights into snacking which could be used to inform nutrition education programs and promote healthier snacking in children. This study showed that morning, afternoon, and evening snacking periods had distinctive characteristics, with the least energy consumed during the morning. Furthermore, in 4- to 8-year-olds, the morning snacking period provided higher densities of calcium and vitamin $\mathrm{C}$, and a lower density of added sugar, suggesting better nutrient quality.

Data were stratified by age because previous studies ${ }^{4,6}$ suggested that younger and older children have different food patterns. In fact, these results showed that 9- to 13-year-olds consumed more energy from savory snacks and sweetened beverages, whereas more 4- to 8-year-olds reported con-suming milk and dairy products and fruit as snacks. There was also a shift from $100 \%$ fruit juices to sweetened beverages from younger to older children, similar to findings in Mexico. ${ }^{20}$ These patterns show that children make less healthy choices about snacking as they approach adolescence. There is no clear explanation for the shift, but it could be influenced by many factors such as influence by parents, peers, media characters, etc. ${ }^{21-23}$ The presence of a parent during proxy-assisted interviews could affect food reporting in both directions, and it is difficult to assess the overall impact. ${ }^{24}$ 
Table 4. Energy Contribution From Each Snacking Period Among 4- to 13-Year-Old US Children, From National Health and Nutrition Examination Survey 2009-2012

Aged 4-8 y

Aged 9-13 y

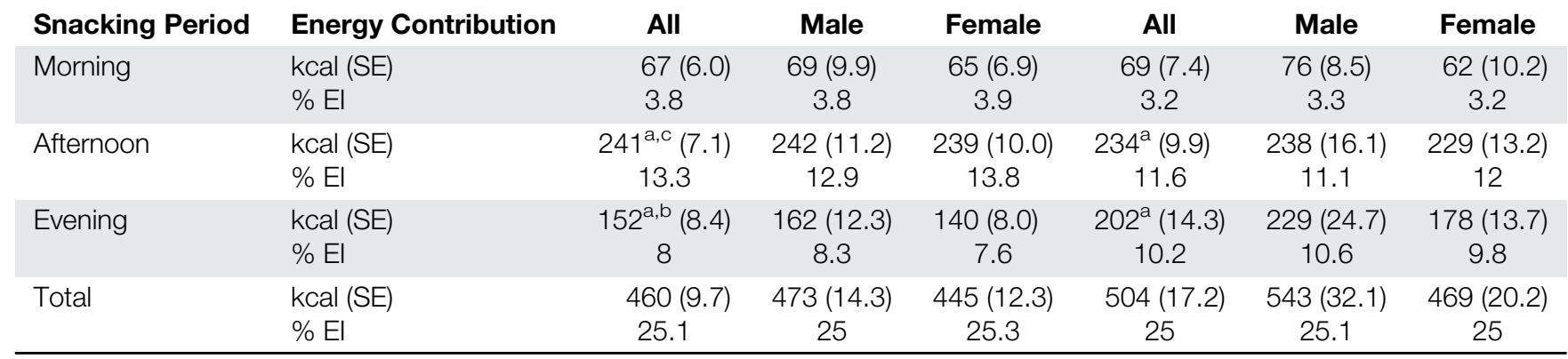

kcal indicates mean energy intake per capita per day; \% El, percent total energy intake.

The superscript indicates significant differences among snacking periods, ie, $P<.05$ when other snacking periods compared to the corresponding values in: ${ }^{\mathrm{a}}$ morning, ${ }^{\mathrm{b}}$ afternoon, and ${ }^{\mathrm{c}}$ evening snacking period, respectively. Student $t$ test was used and Bonferroni adjustment was applied.

Water, including tap water, bottled water, flavored water, and fortified waters, was the most frequently reported food category during snacking periods across both age groups. However, a recent study showed that water consumption in 4- to 13-year-old children was below Institute of Medicine recommendations. ${ }^{25}$ Thus, it is worth exploring how snacking can be used to improve daily fluid intake.

The researchers also evaluated the nutritional quality of snacks consumed during different snacking periods in this study. Sugar density during snacks was much higher than at other meals regardless of the snacking period, owing to the prevalence of sweet bakery products, sweetened beverages, and candy as popular snacking choices. This is a cause for concern. Sugar consumption was associated with hypertension and body weight gain in a recent meta-analysis of randomized controlled trials in adults. ${ }^{26}$ In children, added sugar had a positive association not only with body weight gain $^{27,28}$ but also with childhood cardiovascular disease risk factors. ${ }^{29} \mathrm{~A}$ positive association between sugar intake and the risk of prehypertension and prediabetes was seen in Chinese children. ${ }^{30}$ The reduction of added sugar is therefore an important public health goal. Although sodium density during snacks was lower than at meals, salt reduction should still be targeted because US children have excessive daily total sodium intake. ${ }^{31}$

The choice of foods and beverages consumed during snacking can influ- ence both dietary patterns and nutrient intakes. Interventions to improve snacking quality can be effective in the school setting, as shown in a pilot intervention study with Canadian First Nation students to increase calcium and vitamin D intake. ${ }^{32}$ Children increased their intake of calcium after a week of the intervention but failed to sustain it at 1 year, which suggests the importance of longer-term nutrition education programs as well as the involvement of parents. ${ }^{33}$

The NHANES is a cross-sectional survey; as such, it provides a descriptive snapshot of child snacking habits in the US. A major limitation of crosssectional studies is that they are unable to establish causal relationships between diet and health: for example, the energy consumed or food choices during each snacking period and health outcomes. These surveys rely on self-reported dietary data. Although children at age in this study were assisted by proxies, misreporting still could have occurred, which would have affected the accuracy of intake assessment. Snacking foods and beverages were analyzed at the major and intermediate levels of What We Eat in America food categories in the current study; more information on specific foods and beverages would be useful. In addition, there are no specific dietary guidelines for the number, composition, or timing of snacks. The lack of guidelines or dietary intake recommendations for snacking makes it difficult to assess the nutritional impact of snacks eaten during each snacking period.

\section{IMPLICATIONS FOR RESEARCH AND PRACTICE}

This study takes a first step toward considering the quality of snacks and food groups consumed during morning, afternoon, and evening snacking periods in children. Snacking is a major contributor to total energy intake in US children aged 4 to 13 years, with approximately $25 \%$ of total calories now coming from snacks. Results from this study show that not all daily snacking periods are the same, and that education about the number of times children eat during the day, along with the nutrient quality of the snacks they select, is warranted.

Some of the good habits of younger children, such as milk, cheese, and fruit consumption during snacks, could be emphasized so that these habits could be continued among older children. By looking at which food groups are consumed at different times, targets for improvement can be tailored to foods children are already eating. For example, snacking could be an opportunity to increase water intake and promote intakes of fruit, milk, whole grains, and fiber-containing foods. Replacement of current snacks with nutrient-dense foods could lower the risks of excessive intakes of sugar and sodium and could increase the consumption of nutrients such as calcium and fiber that are inadequately consumed among children. ${ }^{31}$ Reducing sweetened beverage intake at 
Table 5. Nutrient Density at Different Snacking Periods Among 4- to 13-Year-Old US Children, From National Health and Nutrition Examination Survey 2009-2012

\begin{tabular}{|c|c|c|c|c|c|c|c|c|c|}
\hline & \multirow[t]{2}{*}{$\begin{array}{c}\text { Age } \\
4-8 \text { y } \\
9-13 y\end{array}$} & \multicolumn{2}{|c|}{$\begin{array}{c}\text { Meals } \\
n=1,916 \\
n=1,728\end{array}$} & \multicolumn{2}{|c|}{$\begin{array}{l}\text { Morning } \\
n=607 \\
n=442\end{array}$} & \multicolumn{2}{|c|}{$\begin{array}{l}\text { Afternoon } \\
n=1,439 \\
n=1,169\end{array}$} & \multicolumn{2}{|c|}{$\begin{array}{l}\text { Evening } \\
n=1,140 \\
n=1,031\end{array}$} \\
\hline & & Mean & SE & Mean & SE & Mean & SE & Mean & SE \\
\hline Protein & $\begin{array}{l}4-8 \\
9-13\end{array}$ & $\begin{array}{l}4.0 \\
4.1\end{array}$ & $\begin{array}{l}0.0 \\
0.1\end{array}$ & $\begin{array}{l}2.2^{\mathrm{a}} \\
1.6^{\mathrm{a}, \mathrm{d}}\end{array}$ & $\begin{array}{l}0.1 \\
0.1\end{array}$ & $\begin{array}{l}1.9^{\mathrm{a}} \\
2.0^{\mathrm{a}}\end{array}$ & $\begin{array}{l}0.1 \\
0.1\end{array}$ & $\begin{array}{l}2.3^{\mathrm{a}, \mathrm{c}} \\
2.1^{\mathrm{a}}\end{array}$ & $\begin{array}{l}0.1 \\
0.1\end{array}$ \\
\hline Fiber & $\begin{array}{l}4-8 \\
9-13\end{array}$ & $\begin{array}{l}0.8 \\
0.8\end{array}$ & $\begin{array}{l}0.0 \\
0.0\end{array}$ & $\begin{array}{l}0.9 \\
1.1\end{array}$ & $\begin{array}{l}0.1 \\
0.2\end{array}$ & $\begin{array}{l}0.8 \\
0.8\end{array}$ & $\begin{array}{l}0.0 \\
0.0\end{array}$ & $\begin{array}{l}0.7 \\
0.7\end{array}$ & $\begin{array}{l}0.1 \\
0.0\end{array}$ \\
\hline Total fat & $\begin{array}{l}4-8 \\
9-13\end{array}$ & $\begin{array}{l}3.7 \\
3.6\end{array}$ & $\begin{array}{l}0.0 \\
0.0\end{array}$ & $\begin{array}{l}2.7^{\mathrm{a}} \\
2.2^{\mathrm{a}}\end{array}$ & $\begin{array}{l}0.2 \\
0.2\end{array}$ & $\begin{array}{l}3.0^{\mathrm{a}} \\
3.0^{\mathrm{a}, \mathrm{b}}\end{array}$ & $\begin{array}{l}0.1 \\
0.1\end{array}$ & $\begin{array}{l}3.0^{\mathrm{a}} \\
3.1^{\mathrm{a}, \mathrm{b}}\end{array}$ & $\begin{array}{l}0.1 \\
0.1\end{array}$ \\
\hline Saturated fat & $\begin{array}{l}4-8 \\
9-13\end{array}$ & $\begin{array}{l}1.3 \\
1.3\end{array}$ & $\begin{array}{l}0.0 \\
0.0\end{array}$ & $\begin{array}{l}1.0^{\mathrm{a}} \\
0.7^{\mathrm{a}}\end{array}$ & $\begin{array}{l}0.1 \\
0.1\end{array}$ & $\begin{array}{l}1.0^{\mathrm{a}} \\
1.0^{\mathrm{a}, \mathrm{b}}\end{array}$ & $\begin{array}{l}0.0 \\
0.0\end{array}$ & $\begin{array}{l}1.2^{\mathrm{b}, \mathrm{c}} \\
1.2^{\mathrm{b}, \mathrm{c}}\end{array}$ & $\begin{array}{l}0.0 \\
0.1\end{array}$ \\
\hline Total sugar & $\begin{array}{l}4-8 \\
9-13\end{array}$ & $\begin{array}{l}5.9 \\
5.5^{d}\end{array}$ & $\begin{array}{l}0.1 \\
0.1\end{array}$ & $\begin{array}{l}10.6^{\mathrm{a}} \\
12.2^{\mathrm{a}}\end{array}$ & $\begin{array}{l}0.5 \\
0.5\end{array}$ & $\begin{array}{c}10.4^{\mathrm{a}} \\
9.6^{\mathrm{a}, \mathrm{b}}\end{array}$ & $\begin{array}{l}0.2 \\
0.3\end{array}$ & $\begin{array}{l}10.7^{\mathrm{a}} \\
10.9^{\mathrm{a}, \mathrm{b}}\end{array}$ & $\begin{array}{l}0.3 \\
0.4\end{array}$ \\
\hline Added sugar & $\begin{array}{l}4-8 \\
9-13\end{array}$ & $\begin{array}{l}3.1 \\
3.3\end{array}$ & $\begin{array}{l}0.1 \\
0.1\end{array}$ & $\begin{array}{l}5.1^{\mathrm{a}} \\
7.8^{\mathrm{a}, \mathrm{d}}\end{array}$ & $\begin{array}{l}0.4 \\
0.4\end{array}$ & $\begin{array}{l}6.5^{\mathrm{a}, \mathrm{b}} \\
6.5^{\mathrm{a}, \mathrm{b}}\end{array}$ & $\begin{array}{l}0.3 \\
0.3\end{array}$ & $\begin{array}{l}6.7^{\mathrm{a}, \mathrm{b}} \\
7.4\end{array}$ & $\begin{array}{l}0.4 \\
0.3\end{array}$ \\
\hline Calcium & $\begin{array}{l}4-8 \\
9-13\end{array}$ & $\begin{array}{l}61.7 \\
56.9^{d}\end{array}$ & $\begin{array}{l}1.3 \\
1.1\end{array}$ & $\begin{array}{l}91.7 \\
62.2\end{array}$ & $\begin{array}{r}15.0 \\
7.5\end{array}$ & $\begin{array}{l}42.9^{a, b} \\
48.4\end{array}$ & $\begin{array}{l}1.9 \\
5.2\end{array}$ & $\begin{array}{l}61.3^{\mathrm{c}} \\
49.9\end{array}$ & $\begin{array}{l}4.4 \\
4.3\end{array}$ \\
\hline Sodium & $\begin{array}{l}4-8 \\
9-13\end{array}$ & $\begin{array}{l}172.0 \\
181.6^{d}\end{array}$ & $\begin{array}{l}1.9 \\
2.1\end{array}$ & $\begin{array}{r}123.1^{\mathrm{a}} \\
95.0^{\mathrm{a}}\end{array}$ & $\begin{array}{r}15.9 \\
9.0\end{array}$ & $\begin{array}{r}96.0^{\mathrm{a}} \\
128.9^{\mathrm{a}}\end{array}$ & $\begin{array}{r}2.6 \\
16.5\end{array}$ & $\begin{array}{l}90.3^{\mathrm{a}} \\
91.3^{\mathrm{a}, \mathrm{c}}\end{array}$ & $\begin{array}{l}4.1 \\
3.6\end{array}$ \\
\hline Vitamin C & $\begin{array}{l}4-8 \\
9-13\end{array}$ & $\begin{array}{l}4.3 \\
3.7\end{array}$ & $\begin{array}{l}0.2 \\
0.2\end{array}$ & $\begin{array}{r}14.8^{\mathrm{a}} \\
9.4^{\mathrm{a}}\end{array}$ & $\begin{array}{l}2.8 \\
1.9\end{array}$ & $\begin{array}{l}7.1^{a, b} \\
5.6^{a}\end{array}$ & $\begin{array}{l}0.6 \\
0.5\end{array}$ & $\begin{array}{c}10.1 \\
6.8^{\mathrm{a}}\end{array}$ & $\begin{array}{l}2.9 \\
0.7\end{array}$ \\
\hline Vitamin D & $\begin{array}{l}4-8 \\
9-13\end{array}$ & $\begin{array}{l}0.4 \\
0.3^{d}\end{array}$ & $\begin{array}{l}0.0 \\
0.0\end{array}$ & $\begin{array}{l}0.3^{\mathrm{a}} \\
0.2^{\mathrm{a}, \mathrm{d}}\end{array}$ & $\begin{array}{l}0.0 \\
0.0\end{array}$ & $\begin{array}{l}0.2^{\mathrm{a}, \mathrm{b}} \\
0.2^{\mathrm{a}}\end{array}$ & $\begin{array}{l}0.0 \\
0.0\end{array}$ & $\begin{array}{l}0.4^{\mathrm{c}} \\
0.2^{\mathrm{a}}\end{array}$ & $\begin{array}{l}0.0 \\
0.0\end{array}$ \\
\hline
\end{tabular}

Mean indicates the mean nutrient density, expressed as $\mathrm{g} / 100 \mathrm{kcal}$ for protein, fiber, and total and saturated fat, total and added sugar; as mg/100 kcal for calcium and sodium; and as $\mu \mathrm{g} / 100 \mathrm{kcal}$ for vitamins $C$ and $D$.

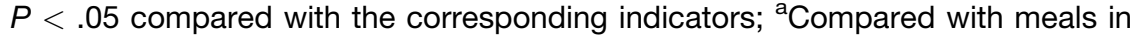
the same age group; ${ }^{b, c}$ Compared with the morning and afternoon snacking periods in the same age group, respectively; ${ }^{d}$ Compared with the same snacking period in the 4- to 8-year-old group.

even 1 snacking period during the day could reduce overall calorie and added sugar intake without forbidding consumption all together. Education of children and caregivers should target foods to promote when children express hunger between meals, in addition to foods that should be limited between meals. Longitudinal and intervention studies are needed to address the health impact of snacking; and further investigation into the potential sociodemographic interaction with snacking will also provide insight into how to use this occasion to balance children's diets to meet their nutritional needs and develop healthy dietary habits.

\section{ACKNOWLEDGMENT}

The authors thank Dr V. Fulgoni (Nutrition Impact, LLC) for his support in data analysis.

\section{REFERENCES}

1. Bellisle F. Meals and snacking, diet quality and energy balance. Physiol Behav. 2014;134:38-43.

2. Piernas C, Popkin BM. Trends in snacking among U.S. children. Health Aff (Millwood). 2010;29:398-404.

3. US Department of Agriculture ARS. Snacks: distribution of snack occasions, by gender and age, What We Eat in
America, NHANES 2011-2012. http:// www.ars.usda.gov/SP2UserFiles/Place/ 80400530/pdf/1112/Table_29_DSO_ GEN_11.pdf. Accessed April 8, 2016.

4. Evans EW, Jacques PF, Dallal GE, Sacheck J, Must A. The role of eating frequency on total energy intake and diet quality in a low-income, racially diverse sample of schoolchildren. Public Health Nutr. 2014;18:1-8.

5. US Department of Agriculture ARS. Snacks: percentages of selected nutrients contributed by food and beverages consumed at snack occasions, by gender and age, What We Eat in America, NHANES 2011-2012. http://www.ars. usda.gov/SP2UserFiles/Place/80400530/ pdf/1112/Table_25_SNK_GEN_11.pdf. Accessed April 8, 2016.

6. Duffey KJ, Rivera JA, Popkin BM. Snacking is prevalent in Mexico. J Nutr. 2014;144:1843-1849.

7. Taillie LS, Afeiche MC, Eldridge AL, Popkin BM. Increased snacking and eating occasions are associated with higher energy intake among Mexican children aged 2-13 Years. J Nutr. 2015; 145:2570-2577.

8. de Castro JM. The time of day of food intake influences overall intake in humans. J Nutr. 2004;134:104-111.

9. de Castro JM. The time of day and the proportions of macronutrients eaten are related to total daily food intake. $\mathrm{Br} J$ Nutr. 2007;98:1077-1083.

10. de Castro JM. When, how much and what foods are eaten are related to total daily food intake. Br J Nutr. 2009;102: 1228-1237.

11. Bo S, Musso G, Beccuti G, et al. Consuming more of daily caloric intake at dinner predisposes to obesity: a 6-year population-based prospective cohort study. PLoS One. 2014;9:e108467.

12. Bo S, De Carli L, Venco E, et al. Impact of snacking pattern on overweight and obesity risk in a cohort of 11- to 13year-old adolescents. J Pediatr Gastroenterol Nutr. 2014;59:465-471.

13. Kinsey AW, Ormsbee MJ. The health impact of nighttime eating: old and new perspectives. Nutrients. 2015;7: 2648-2662.

14. Zipf G, Chiappa M, Porter KS, et al. National Health and Nutrition Examination Survey: plan and operations, 1999-2010. Vital Health Stat. 2013;1(56):1-37.

15. Raper N, Perloff B, Ingwersen L, Steinfeldt L, Anand J. An overview of USDA's dietary intake data system. J Food Compost Anal. 2004;17:545-555. 
16. US Department of Agriculture ARS. What We Eat in America food categories. http://www.ars.usda.gov/SP2User Files/Place/80400530/pdf/1112/food_cate gory_list.pdf. Accessed April 8, 2016.

17. Kerr MA, McCrorie TA, Rennie KL, Wallace JM, Livingstone MB. Snacking patterns according to location among Northern Ireland children. Int J Pediatr Obes. 2010;5:243-249.

18. Boyer LE, Laurentz S, McCabe GP, Kranz S. Shape of snack foods does not predict snack intake in a sample of preschoolers: a cross-over study. Int J Behav Nutr Phys Act. 2012;9:94.

19. Gilbert JA, Miller D, Olson S, St-Pierre S. After-school snack intake among Canadian children and adolescents. Can J Public Health. 2012;103:e448-e452.

20. Barquera S, Campirano F, Bonvecchio A, Hernandez-Barrera L, Rivera JA, Popkin BM. Caloric beverage consumption patterns in Mexican children. Nutr J. 2010;9:47.

21. van Ansem WJ, Schrijvers CT, Rodenburg G, van de Mheen D. Children's snack consumption: role of parents, peers and child snack-purchasing behaviour. Results from the INPACT study. Eur J Public Health. 2015;25: 1006-1011.
22. Salvy SJ, Elmo A, Nitecki LA, Kluczynski MA, Roemmich JN. Influence of parents and friends on children's and adolescents' food intake and food selection. Am J Clin Nutr. 2011;93:87-92.

23. Kotler JA, Schiffman JM, Hanson KG. The influence of media characters on children's food choices. J Health Commun. 2012;17:886-898.

24. Bornhorst C, Huybrechts I, Ahrens W, et al. Prevalence and determinants of misreporting among European children in proxy-reported $24 \mathrm{~h}$ dietary recalls. Br J Nutr. 2013;109:1257-1265.

25. Drewnowski A, Rehm CD, Constant F. Water and beverage consumption among children age 4-13y in the United States: analyses of 2005-2010 NHANES data. Nutr J. 2013;12:85.

26. Malik AH, Akram Y, Shetty S, Malik SS, Yanchou Njike V. Impact of sugarsweetened beverages on blood pressure. Am J Cardiol. 2014;113:1574-1580.

27. Malik VS, Pan A, Willett WC, Hu FB. Sugar-sweetened beverages and weight gain in children and adults: a systematic review and meta-analysis. Am J Clin Nutr. 2013;98:1084-1102.

28. Te Morenga L, Mallard S, Mann J. Dietary sugars and body weight: systematic review and meta-analyses of randomised controlled trials and cohort studies. BMJ. 2013;346:e7492.

29. Kell KP, Cardel MI, Bohan Brown MM, Fernandez JR. Added sugars in the diet are positively associated with diastolic blood pressure and triglycerides in children. Am J Clin Nutr. 2014;100:46-52.

30. Piernas C, Wang D, Du S, et al. Obesity, non-communicable disease (NCD) risk factors and dietary factors among Chinese school-aged children. Asia Pac J Clin Nutr. September 2015. http:// dx.doi.org/10.6133/apjen.092015.37.

31. Hess J, Slavin J. Snacking for a cause: nutritional insufficiencies and excesses of U.S. children, a critical review of food consumption patterns and macronutrient and micronutrient intake of U.S. children. Nutrients. 2014;6:4750-4759.

32. Gates M, Hanning RM, Gates A, McCarthy DD, Tsuji LJ. Assessing the impact of pilot school snack programs on milk and alternatives intake in 2 remote First Nation communities in northern Ontario, Canada. J Sch Health. 2013;83:69-76.

33. Williams PA, Cates SC, Blitstein JL, et al. Nutrition-education program improves preschoolers' at-home diet: a group randomized trial. J Acad Nutr Diet. 2014;114:1001-1008. 


\section{CONFLICT OF INTEREST}

The authors have not stated any conflicts of interest. 